\title{
ICT INVESTMENT, PRODUCTIVITY AND \\ EFFICIENCY: EVIDENCE AT FIRM LEVEL USING A STOCHASTIC FRONTIER APPROACH
}

by

Luigi Paganetto, Leonardo Becchetti and

David Andres Londono Bedoya

\section{Introduction}

The relationship between information and communication technology (from now on also ICT) ${ }^{1}$ and productivity has long been debated over the past three decades. In the 1980s and in the early 1990s, empirical research generally did not find relevant productivity improvements associated with ICT investments (Strassmann, 1990; Lovemann, 1988; Bender, 1986; Franke, 1987; Roach, 1989). This research showed that there was no statistically significant, or even measurable, association between ICT investments and productivity at any level of analysis chosen. Robert Solow commented this puzzle by saying that " we find computer everywhere, except in the productivity statistics." Various rationales have been suggested to explain this paradox. First, simple bivariate correlations between aggregate productivity and aggregate ICT capital stock do not take into account the impact of all controls which also affect aggregate productivity and are therefore likely to measure spurious effects (Lehr-Licthemberg, 1999). Second, ICT investment has a positive effect on productive variety which may, in turn, negatively affect

\footnotetext{
${ }^{1}$ Information Technology is defined by the US Bureau of Economic Analysis as: "Office, computing and accounting machinery". As many researchers do we add to it communication equipment, software and related services.
} 
productivity (Brooke, 1991). Milgrom-Roberts (1988) show for instance that computer aided design (CAD) reduces costs of adjusting products to changing consumer tastes. This shifts productive organisation from the Fordist approach to a more flexible network approach which emphasizes economies of scope more than economies of scale. Since variety is hard to detect than quantity it is difficult to find trace of these changes in data. Third, productivity gains from ICT investment materialise only after time and depend significantly on network externalities and on changes in the complementary infrastructure (David, 1990). Fourth, output measurement errors may affect estimates of the impact of ICT investment on output as quality improvements in products and in services are not fully reflected in sales. Fifth, ICT accounts for a relatively small share of capital output so that its increase has only small effects on aggregate output.

More recently, as new data were made available and new methodologies were applied, empirical investigations have found evidence that ICT is associated with improvements in productivity, in intermediate measures and in economic growth (Oliner and Sichel, 1994; Lehr-Licthemberg, 1999; Sichel, 1997; Brynjolfsson and Hitt, 1996). An interpretation consistent with older and more recent results is that micro level data, by allowing the use of more controls, succeed better than aggregate measures in isolating ICT effects on productivity from changes in other conditioning variables. A first direction for improving the last vintage of empirical approaches is disaggregation of the impact of ICT into the contributions of components with different effects and characteristics (such as software, hardware and telecommunications). A second direction is going beyond the adoption of two-stage estimation procedures (production function and then separately an estimation in which the dependent variable is the residual from the first equation) which inconsistently assume the independence of the inefficiency effects in the two estimation stages and are likely to be inefficient. 
This paper follows this approach showing that microfounded estimates of efficiency at firm level, which include several quantitative and qualitative controls traditionally used by the literature, confirm the result of a positive and significant impact of ICT investment on productive efficiency found by the most recent literature. The paper also shows that it is possible to understand better the impact of ICT investment by decomposing it into software and telecommunications. Software investment has scale effects by increasing labour productivity, the demand for high skilled workers and the overall firm productive efficiency for a given amount of inputs. Telecommunications investment has scope effects by positively affecting the creation of new processes or products, while negatively affecting average labour productivity. The combination of these two effects, increases productive efficiency and utilisation capacity.

In the theoretical section of the paper these results are explained in the framework of the real option theory. We argue that changes in products and processes induced by ICT investment $^{2}$, reduce lags between knowledge of changing consumer tastes and final production. These changes generate a flexibility option which, at any instant of time, delays the decision to invest in additional capacity and makes the decision to modify products and processes more likely thereby generating the observed effects on productivity and capacity utilisation.

The paper is divided into six sections (including introduction and conclusions). The second section presents a review of the literature with a brief illustration of the theoretical predictions and the main empirical findings on the relationship between ICT

\footnotetext{
${ }^{2}$ To find significant examples which support this hypothesis see analyses of the effects of the creation of call centers (Aksin- Harker, 1999), of the introduction of CAD/CAM (Computer Aided Design and Computer Aided Manufacture) Milgrom- Roberts, 1988), and ERP (Enterprise Resource Planning) (ClausenKoch, 1999; Wright-Burns, 1997). All these changes in firm organisation of production process and customer relationship are induced by ICT investment.
} 
technology and productivity. The third section presents descriptive empirical evidence on the intensity of investment in hardware, software and telecommunications in a representative sample of more than 4000 Italian firms between 1995 and 1997 showing how ICT investment is affected by industry, geographical and qualitative firm characteristics. The fourth section analyses the effects of ICT investment on several intermediate variables such as capacity utilisation, new product/process introduction and white collars hiring rates at firm level. The fifth section presents several estimates which evaluate the association between ICT investment and the distance from the "efficiency frontier."

\section{Descriptive empirical findings on ICT investment intensity in Italy}

We evaluate the intensity of ICT investment and its impact of various productivity measures using the Mediocredito Survey. The Survey includes a sample of more than 5000 firms drawn from the whole set of Italian manufacturing firms. The sample is stratified according to industry, geographical and dimensional distribution of Italian firms for firms from 11 to 500 employees. It is by census for firms with more than 500 employees. For a subsample of 4,404 firms both qualitative and quantitative data (balance sheets for the 1995-1997 period) are collected. Qualitative data provide, among other things, information about ownership structure ${ }^{3}$, internationalisation,

\footnotetext{
${ }^{3}$ The richness of the dataset of Italian firms allows to overcome some traditional problems in the estimates of the impact of ownership and control on firm performance. The first problem is about the proxy adopted to identify ownership-controlled (OC) and manager-controlled (MC) firms which is usually based on percentage ownership criteria (Short, 1994).Cubbin-Leech (1983) and Leech-Leahy (1991) are among the few exceptions to the use of the ownership
} 
$R \& D$ investment, and successful introduction of products and processes. $^{4}$

Descriptive features of this sample illustrate some important characteristics of the Italian ICT investment per employee (Table 1) evaluated as the sum of investment in software, hardware and telecommunications in the three considered years. The average ICT cumulative investment per employee in the sample is 7 million liras. The following deviations from this value worth noting. Per capita ICT investment is on average: i) more than a half lower in firms located in the South; ii) much higher in firms located in the North-East; iii) substantially higher for small firms and (as expected) for firms in the Specialised industries according to the Pavitt classification (mechanical equipment and mechanical materials); iv) ownership structure and financial constraints seem to matter as firms with only one controlling shareholder and firms with financial constraints have a relatively lower intensity of ICT investment; v) firms participating to credit and export consortia also have relatively lower ICT investment per employee. ${ }^{5}$

When we disaggregate ICT investment into hardware, software and telecommunications components we find that: i) software and hardware investment per employee in North-East (in the South) is

percentage criteria. They consider complex patterns of shareholdings, kinship networks and interlocking directories. It is well known that, as firms grow in size, control may be exerted with a limited ownership share and that a univocal relationship between the two variables does not exist at low ownership-control shares.

${ }^{4}$ The following selection bias of the Mediocredito dataset must be taken into account. More than 90 percent of observed small firms (below 50 employees) are "società di capitali" (entrepreneurs have limited liability) while this share is much lower and unlimited liability is widespread in the universe of Italian small firms. When interpreting empirical results we must therefore consider that we are analysing the subset of Italian small and medium sized firms with the most "evolved" form of corporate governance.

${ }^{5}$ This last finding could be partially explained by the fact that ICT endowment of other participants to consortia and of consortia themselves may partially substitute for their own investment. 
almost double (half) as much as national average; ii) software and hardware investment intensity is also relatively higher in Specialised industries and in R\&D investing firms. The pattern of telecommunications investment is quite different. Intensity is higher in larger firms and in firms affiliated to groups and its geographical distribution is not so different across macroareas.

3. Four hypotheses on the impact of ICT investment: theoretical rationales and empirical tests

To investigate the effects of ICT investment we disaggregate it into different components and test their impact on productivity at firm level. The survey of the existing literature and the theoretical analysis - described in detail in the Appendix - lead us to formulate 4 hypotheses which we briefly explain and test in the following sections of the paper.

Hypothesis 1: investment in software increases the demand for skilled labour

This hypothesis has been already supported by Roach (1991), Berndt et al. (1992) and Stiroh (1998) which argue that, even though ICT may substitute for labour, it also increases white collar productivity and white collars hiring rates.

This proposition is the obvious outcome of cost minimisation under the assumption that an increase in the stock of ICT capital raises more the marginal productivity of skilled vis-à-vis that of unskilled labour. In this case, if the market for skilled labour is competitive or if skilled labour wage is not too upward sloping in the number of skilled workers hired, only an increase in the number of skilled workers may restore the equilibrium condition which states that the ratio of wages between two factors must equal the ratio between their marginal productivities. Descriptive evidence does not contradict our hypothesis as software investing 
firms have an average yearly hiring rate of 0.6 per cent against a 0.3 per cent of the rest of the sample. We test our proposition on a regression model which includes five types of controls (industry, location, identity, ownership, finance, innovation and human and physical capital) and which is described in detail in the Appendix A1. The justification for using all these controls is that these five types of variables have been widely demonstrated to affect all relevant firm choices (hiring included). ${ }^{6}$ Nonetheless, traditional empirical papers just use the first three types of controls (industry,location and identity) for scarcity of data. The richness of our dataset enables us to use all of them reducing the risk that our significant relationships proxy for unobserved variables.

Since the dependent variable is clearly nonnormal (Tab. A1.1) and left censored we use a Tobit model and evaluate the significance of coefficients with percentile and bias corrected bootstrapping techniques.

By estimating our model we empirically find a positive and significant effect of aggregate ICT investment and of software investment on the demand for high skilled workers ${ }^{7}$ (telecommunications and hardware seem to have no impact) which supports our theoretical hypothesis (see Tab A1.2 in the Appendix). This effect is significant net of the relationship that other controls have on the dependent variable (the positive and significant impact of size, export capacity, government subsidies, affiliation to group and the negative and significant impact of government ownership). Since we are aware that in case of overparametrisation the relative significance of individual

\footnotetext{
${ }^{6}$ The reader can check Short (1994) for a detailed survey on the effect of ownership on firm choices (leverage, performance, ecc.); Chirinko (1993) for the impact of the availability of external finance on firm decisions; Gale (1991) and Schwarts-Clements (1999) for the impact of state subsidies on firm performance and Aw-Hwang, (1995), Clerides-Lach-Tybout (1998) and Becchetti-Santoro (2000) for the effect of internationalisation on firm efficiency. 7 We use the ratio of high skilled (graduated) workers hired to total firm employees as a dependent variable.
} 
regressors may be blurred by reduced efficiency and multicollinearity among regressors, we also run a stepwise regression using 95 percent significance as a threshold to see whether exclusion/inclusion of insignificant controls and eventual correlation among regressors generate a spurious relationship between software investment and the demand for skilled workers. The relationship is confirmed and reinforced under the stepwise procedure (Tab. A1.3).

Hypothesis 2: investment in telecommunications positively affects the introduction of new products or processes

Previous papers argue that ICT investment has a positive effect on productive variety (Brooke, 1991; Barua-KriebelMukhopadhyay, 1991). We show here that this hypothesis is confirmed but that the increased variety effect must be attributed to telecommunications only and not to software and hardware investment. If telecommunications investment (such as the introduction or implementation of e-commerce, intranet and internet communication and network production) allows the firm to know in real time consumer tastes and to adapt more quickly its productive process to satisfy consumers' taste for variety, the introduction of new processes and products should be positively affected by it. Descriptive evidence strongly supports this hypothesis as 69 percent of telecommunication investing firms declare they have introduced new products against 30 percent of the rest of the sample. Empirical results show that investment in telecommunications for firms participating to groups is positively and significantly related to the decision to introduce new products (Tab A1.2). The interesting finding is that the effect is not significant for those firms which invest in telecommunications but are not part of a group. The intepretation is that the scope and flexibility effect of this kind of ICT investment can be achieved only in an integrated network productive system which is typical of industrial groups. Logit results also show that family 
ownership, participation to traditional sectors and investment in hardware (R\&D investment, credit rationing and participation to credit consortia) seem to affect negatively (positively) the dependent variable. The negative impact of hardware may be interpreted by considering that hardware investment is mainly related to an individual and specific production process, entails much more sunk costs and reduces flexibility and opportunities for introducing new processes. Stepwise estimates confirm the effect of all the above mentioned variables while some other controls previously significant in the overall estimate are dropped (tab. A1.1-A1.3). When we consider as a dependent variable the introduction of both products and processes the positive impact of telecommunications investment is confirmed. An interesting result is also the different effect of investment subsidies negative - and tax allowances - positive - which shows that when government support - as it is in the case of tax allowance - is not related to a specific investment in physical capital (and often to the renovation of the existing capital stock) it increases flexibility and capacity of introducing new products or processes.

Hypothesis 3: the investment in Information Technology increases the value of the firm by adding a flexibility option whose effect is that of increasing average capacity utilisation .

The hypothesis of a positive relationship between capacity utilisation and ICT has been formulated by Barua-KriebelMukhopadhyay (1991). We find support for it on our data and provide a theoretical rationale by using a simple dynamic programming example.

Consider the decision to increase productive capacity to satisfy a potential increase in demand under uncertainty as a real option in a simple dynamic approach. If telecommunications investment, reduces lags between knowledge of current customer tastes and 
final production, ${ }^{8}$ it also has the effect of enlarging the time window in which the firm may adapt its capacity to satisfy market demand. Telecommunications investment therefore creates an option for flexibility transforming the investment in the capacity increase from a "now or never" investment into a decision which can be postponed. In this framework, for certain values of model parameters, the decision to wait is preferred to the decision to "invest now" in additional capacity if the firm has previously invested in telecommunications. For the same parameter values the firm would have invested now in additional capacity if the ICT investment had not occured and the opportunity to delay were not available. Given the positive probability ex post of the realisation of the negative state of nature the non ICT firm will find herself with expected lower additional capacity, contrary to the ICT firm which can postpone the investment decision after the observation of the stock. In a theoretical Appendix we show that this result holds with both simple two period discrete and continuous time stochastic processes (see Appendix 2).

Empirical results are consistent with our hypothesis on the effects of telecommunications investment on capacity utilisation. The

\footnotetext{
${ }^{8}$ As specified in the Appendix with more analytical detail we may think of an investment in telecommunications as having a B2C (business to consumer) and a B2B (business to business) effect. The first enables producers to know in real time, through internet communication, consumer tastes and the demand for differentiated products of the firms (consider for instance the recent development of "call centers" as an emerging marketing tool in which ICT allows to intensify contacts between a firm and its consumers). The second allows through internet and intranet communication the reduction of production lags and informational asymmetries among subcontractors and component producers at different levels of the chain value (i.e. the creation of "digital auction markets" for specific product chains increases the number of participants, reduces transaction costs and reduces lags between the definition of new product characteristics adapting to changed consumer tastes and its availability to final consumers). In our model this creates for the ICT investing firm the possibility to invest and adapt production in the same period in which consumer tastes are known.
} 
interesting point is that the effect is positive only when firms are part of a group. This may be interpreted by saying that the crucial factor in generating the flexibility option is the network productive organisation. In the language of our theoretical model the critical factor is not just the capacity of knowing consumer tastes in real time (B2C effect) but mainly the capacity of a more flexible productive organisation (B2B effect) which reduces lags between knowledge of consumers' taste for variety and the final production of a complex diversified range of products which assemble different components.

Hypothesis 4: investment in telecommunications reduces the average productivity of labour, while investment in software increases it.

In our previous hypotheses we argued that telecommunications investment extends the window in which the decision to increase productive capacity may be taken and gives firms not only the opportunity to expand capacity but also to change products and processes to satisfy consumers taste for variety. If this is true telecommunications investing firms are more likely, at any instant of time, to shift firm activity to new products or processes by paying though, when this decision is taken, the cost of reduced productivity of labour inputs which need to be retrained because of these changes (Kyley, 1999).

On the other hand, the effect of software investment on average labour productivity is the consequence of hypothesis 1 as new workers are hired, the new software technology increases the marginal productivity of each individual worker and average labour productivity is higher. ${ }^{9}$ Given the nonnormal distribution of the dependent variable (Tab. A 1.3) we evaluate the effect of our set of regressors on two points of the distribution of the

\footnotetext{
${ }^{9}$ Only with a wage which is insensitive to the total number of employees the marginal productivity of the last worker hired would be the same as before.
} 
dependent variable (conditional mean and conditional median). Empirical results on the determinants of labour productivity seem consistent with our theoretical conclusions. In the estimate with all controls software and telecommunications investments have the expected sign even though the impact of telecommunications is significant only on conditional mean and not on conditional median. These two regressors resist to the stepwise selection and substantially reinforce their significance together with expected controls such as capital stock per employee and multiple borrowing (Tab. A 1.3).

5. ICT investment and firm efficiency: a stochastic frontier approach

The empirical approach followed so far has the defect of not being rigorously microfounded. The stochastic frontier approach followed in the next section will amend this problem and test whether different types of ICT investment significantly affect the distance from the optimal production frontier in our sample. We estimate the impact of ICT investment on efficiency at firm level by using a traditional stochastic frontier approach (Battese and Coelli, 1995). In this model the inefficiency effects are expressed as an explicit function of a vector of firm-specific variables and a random error ${ }^{10}$

10 This approach has been widely recognised superior to the two-stage estimation which inconsistently assumes the independence of the inefficiency effects in the two estimation stages. The two-stage estimation procedure is unlikely to provide estimates which are as efficient as those that could be obtained using a single-stage estimation procedure. 
The first equation is a five input Cobb-Douglas production function and is specified as follows:

$$
\begin{aligned}
& Y_{i t}=\alpha_{0}+\sum_{j=1}^{m-1} \alpha_{j} * \text { Ind }{ }_{j}+\beta_{1} K_{i t}+\beta_{2} H S L_{i t}+\beta_{3} L S L_{i t}+\beta_{4} R M_{i t}+ \\
& +\beta_{4} I I_{i t}+v_{i t}-u_{i t}
\end{aligned}
$$

$Y$ is the $\log$ of real output of the $\mathrm{i}^{\text {th }}$ firm at time $\mathrm{t}(i=1, \ldots, N$; $t=1, \ldots, T) ; K$ is the $\log$ of the capital stock evaluated at the replacement cost, HSL, LSL, RM and II represent additional inputs (and are respectively the log of high skilled and low skilled workers, raw materials and intermediate inputs). Since any industrial sector may have in principle a different production function we add to the specification $m-1$ intercept dummies for 20 sectors aggregated on the basis of the four digit ISTAT-ATECO classification. This solution is not completely satisfactory as industry production functions may also differ in input marginal productivities. We therefore estimate the model separately for each industry for which we have enough degrees of freedom. ${ }^{11}$ The $v_{i t}$ are random variables which are assumed to be iid. $N\left(0, \sigma_{V}{ }^{2}\right)$, and independent of the $u_{i t}$. The latter are nonnegative random variables which are assumed to account for technical inefficiency in production and are assumed to be independently distributed as truncations at zero of the $N\left(m_{i}, \sigma_{U}{ }^{2}\right)$ distribution where $\quad m_{i t}=z_{i t} \delta,(2), \quad z_{i t}$ is a $p \times 1$ vector of

\footnotetext{
${ }^{11}$ Estimates with a simpler two inputs Cobb-Douglas production function for the overall sample with dummies accounting for differences in industry slopes have also been performed with results on the impact of ICT investment on productive efficienty which are not substantially different from those obtained with the five input aggregate and industry estimates. These additional estimates are available from the authors upon request.
} 
variables which may influence the efficiency of a firm; and $\delta$ is an $1 \times p$ vector of parameters to be estimated.

Following Battese and Coelli (1993), we replace $\sigma_{V}{ }^{2}$ and $\sigma_{U}{ }^{2}$ with $\sigma^{2}=\sigma_{V}{ }^{2}+\sigma_{U}{ }^{2}$ and $\gamma=\sigma_{U}{ }^{2} /\left(\sigma_{V}{ }^{2}+\sigma_{U}{ }^{2}\right)$. The log-likelihood function of this model is described in Battese and Coelli (1993).

The nonzero mean residual of the production function is regressed on a series of factors which are expected to affect efficiency:

$$
\begin{aligned}
& u_{i t}=\alpha_{0}+\sum_{i=1}^{m-1} \alpha_{i} \text { Ind } d+\sum_{k=1}^{n-1} \gamma_{k} \text { Macroarete } \delta_{1} \text { Youn } \delta_{2} \text { Old }+\delta_{3} \text { Group } \delta_{4} \text { Csa\# } \\
& +\delta_{5} \text { Qtnosetp } \delta_{6} \text { Family } \delta_{7} C S S A \delta_{8} \text { Ration } \delta_{9} \text { Rents }+\delta_{10} \text { Presf } t+\delta_{11} \text { Innovtu } \\
& +\delta_{12} C a * \delta_{13} J C T+\varepsilon_{i t}
\end{aligned}
$$

First, we introduce factors traditionally considered in the literature (Hay-Liu, 1997; Nickell, 1996 and Nickell-NicolitsasDryden, 1997) such as CAP (the degree of capacity utilisation), RENTS - ((profits before tax+depreciation+interest payments-cost of capital*capital stock)/value added) and PRESFI - interest payments/ (interest payment + cash flow). IND, MACROAREA, SIZE, GROUP, QTNOSEP and FAMILY are specified as in Appendix 1.

We then add two dummies $(O L D, Y O U N G)$ respectively picking up the older and the younger 20 percent of sample firms. An additional control (which we expect to be positively related to productive efficiency) is represented by CSAT and CSSA, two dummies respectively picking up firms monitoring customer satisfaction and firms which created sale structures abroad. ${ }^{12}$ INNOVAT is a dummy for firms which succesfully introduced

12 The literature investigating the relationship between efficiency and internationalisation usually finds a two-way positive relationship between internationalisation and productivity (Aw-Hwang, 1995; Clerides-Lach-Tybout, 1998 and Becchetti-Santoro, 2000). The variable is therefore an important control to be considered in order to avoid omitted variable biases. 
new products or processes. Finally, ICT is the average ICT investment per employee.

The model is estimated as a cross-section in which all variables are expressed as three year averages. We adopt two different specifications. In the first ICT investments are considered jointly, while in the second they are disaggregated into software, hardware and telecommunications investment per employee.

On the whole the model seems to fit well our data and the presence of technical inefficiencies is supported by the positive and significant gamma coefficient (tab. 3).

Estimate results show that aggregate ICT investment has a positive and significant effect on firm efficiency and that software has positive (negative) effect when individually considered. Telecommunications investment has a weakly significant negative effect on efficiency. These findings show the existence of a symmetry between effects of ICT inputs on average labour productivity and on productive efficiency for a given level of inputs (Tab A1.3).

Other controls give expected results. Firms located in the South, older firms and firms which declared to be credit rationed are significantly less efficient than average consistently with previous findings (Becchetti-Santoro, 2000). The result on rents is consistent with all the traditional literature on the effects of competition on efficiency. ${ }^{13}$ The hypothesis that financial pressure increases managerial discipline (Jensen, 1986 and 1988; Aghion et al., 1995) is supported by our data only in the extended

\footnotetext{
${ }^{13}$ According to it, competition has positive effects on efficiency (Short, 1994; Nickell, 1995; Vickers, 1995): i) by making it easier for owners to compare managerial performance with that of competitors; ii) by increasing the advantage of higher efficiency under the form of cost reductions as the latter are more profitable under competition where demand elasticities are higher; iii) by leading managers to work harder in order to avoid bankruptcy which is more likely to occur in a tight market (Schmidt, 1996; Aghion-Howitt, 1996).
} 
specification in which ICT investment is disaggregated into its three different components. Industry estimates show that the aggregate significance of the effect of ICT investment is determined by the behaviour of some and not of all considered sectors (tab. 3). Estimates have been performed only for those industries (7 out of 19) for which we dispose of enough degrees of freedom. The ICT coefficient significantly affects productive efficiency in five industries (Mechanical materials, Mechanical Equipment, Textile, Wood and Wooden Furniture, Paper and Printing) while in the other two (Metal Products, Food and Beverages) is not significant.

\section{Conclusions}

Simple intuition from experience in various professional fields (including the academia) suggests that the increase in productivity from an improvement in software technology (more powerful word processing and printing, etc.) is positively related to the skills of the labour inputs. In the same way, an improvement in telecommunications techology (such as the opportunity of internet or intranet networking, the introduction of e-mail, e-commerce, etc.) increases the inflow of available information thereby generating a flexibility option which will make more expensive and which will delay irreversible decisions such as new investments. This option will generate at the same time the opportunity to differentiate more quickly processes and products in order to satisfy consumers' taste for variety.

We therefore expect that, at any instant of time, a firm investing in telecommunications will delay investment in additional capacity and introduce new products and processes with a higher probability. We also expect this firm to have a higher capacity utilisation and a lower average labour productivity if introduction of new products and processes goes together with a learning phase in which productive inputs have to be retrained. 
What we should observe therefore is an increase in the demand for skilled workers and in average labour poductivity after a software investment and an increase in capacity utilisation together with a reduced average labour productivity and an increase in the introduction of new products and processes after a telecommunications investment.

These results open interesting directions for future research. Which is the combined effect of higher productivity and reduced investment intensity generated by the option to delay on the rate of growth ? Is the volume of high-tech investment socially optimal and, if not - considered that increased capacity utilisation must be related with a lower rate of growth of the physical capital stock and considered the positive externality of this type of investment on the rest of the economy -, which measures can be taken to reduce the incentive of high-tech firms to delay? We think that answers may be found on fiscal and monetary policies and on the governance of financial markets and that the different ability to implement measures in these three directions is significantly affecting the capacity of different countries of translating benefits of the new economy into higher rates of growth. 
Table 1 Descriptive findings on the determinants of ICT investment (95-97 ICT investments per employee - millions of liras)

\begin{tabular}{|c|c|c|c|c|c|c|c|c|c|c|}
\hline CT Investments per & \multicolumn{2}{|c|}{ South and isles } & \multicolumn{2}{|c|}{ Centre } & \multicolumn{2}{|c|}{ North-West } & \multicolumn{2}{|c|}{ North-East } & \multicolumn{2}{|c|}{ ITALY } \\
\hline & $\begin{array}{l}\text { N.of } \\
\text { obs }\end{array}$ & Mean & $\begin{array}{l}\begin{array}{l}\text { N. of } \\
\text { obs }\end{array} \\
\end{array}$ & Mean & $\begin{array}{l}\text { N. of } \\
\text { obs }\end{array}$ & Mean & $\begin{array}{l}\text { N. of } \\
\text { obs }\end{array}$ & Mean & $\begin{array}{l}\text { N. of } \\
\text { obs }\end{array}$ & Mean \\
\hline All firms & 338 & 2.87 & 354 & 6.05 & 1386 & 5.42 & 802 & 12.06 & 2980 & 7.16 \\
\hline Small size & 188 & 3.00 & 315 & 4.65 & 750 & 7.23 & 457 & 19.57 & 1710 & 9.59 \\
\hline Large size & 86 & 2.46 & 80 & 13.67 & 413 & 3.25 & 208 & 3.48 & 787 & 4.28 \\
\hline Scale sectors & 100 & 2.21 & 129 & 6.43 & 413 & 10.22 & 205 & 4.29 & 847 & 7.26 \\
\hline Traditional sectors & 163 & 2.65 & 223 & 2.81 & 483 & 2.89 & 302 & 2.79 & 1171 & 2.82 \\
\hline Specialised sectors & 37 & 4.27 & 80 & 4.91 & 424 & 3.64 & 264 & 31.47 & 805 & 12.92 \\
\hline \multicolumn{11}{|c|}{ Ownership structure } \\
\hline Family owned & 196 & 2.40 & 262 & 3.77 & 869 & 6.70 & 483 & 3.77 & 1810 & 5.03 \\
\hline $\begin{array}{l}\text { Banks among } \\
\text { controlling } \\
\text { shareholders }\end{array}$ & 8 & 1.57 & 12 & 4.10 & 63 & 3.37 & 33 & 4.12 & 116 & 3.53 \\
\hline Privately owned & 193 & 2.61 & 265 & 6.11 & 813 & 5.08 & 496 & 18.49 & 1767 & 8.61 \\
\hline State owned & 6 & 5.90 & 5 & 2.70 & 7 & 2.73 & 1 & 0.39 & 19 & 3.60 \\
\hline $\begin{array}{l}\text { Onecontrolling } \\
\text { shareholder }\end{array}$ & 38 & 2.00 & 28 & 2.33 & 45 & 3.06 & 43 & 2.17 & 154 & 2.42 \\
\hline \multicolumn{11}{|c|}{ R\&D, external finance, group and consortia affiliation } \\
\hline $\mathrm{R} \& \mathrm{D}$ investments & 88 & 4.53 & 178 & 8.77 & 607 & 5.98 & 333 & 25.23 & 1206 & 11.60 \\
\hline Credit rationed firms & 21 & 2.08 & 17 & 2.68 & 45 & 3.03 & 25 & 2.61 & 108 & 2.69 \\
\hline Subsidised firms & 241 & 2.60 & 210 & 9.40 & 609 & 3.20 & 350 & 3.93 & 1410 & 4.20 \\
\hline $\begin{array}{l}\text { Affiliated to } \\
\text { nondiversified groups }\end{array}$ & 83 & 3.12 & 83 & 14.90 & 318 & 3.65 & 201 & 3.99 & 685 & 5.05 \\
\hline $\begin{array}{l}\text { Affiliated to Export } \\
\text { consortia }\end{array}$ & 6 & 3.55 & 25 & 2.35 & 28 & 2.76 & 16 & 4.01 & 75 & 2.95 \\
\hline $\begin{array}{l}\text { Affiliated to credit } \\
\text { consortia }\end{array}$ & 15 & 2.51 & 19 & 4.26 & 66 & 2.53 & 56 & 3.32 & 156 & 3.06 \\
\hline Variable & \multicolumn{2}{|c|}{$\begin{array}{l}\text { South \& } \\
\text { isles }\end{array}$} & Centre & \multicolumn{3}{|c|}{ North-West } & Jorth-Eas & & \multicolumn{2}{|c|}{ ITALY } \\
\hline $\begin{array}{l}\text { Telecommunication } \\
\text { Investment per } \\
\text { employee }\end{array}$ & $\begin{array}{l}\text { N. of } \\
\text { obs }\end{array}$ & Mean & $\begin{array}{l}\text { N. of } \\
\text { obs }\end{array}$ & Mean & $\begin{array}{l}\text { N. of } \\
\text { obs }\end{array}$ & Mean & $\begin{array}{l}\text { N. of } \\
\text { obs }\end{array}$ & Mean & $\begin{array}{l}\text { N. of } \\
\text { obs }\end{array}$ & Mean \\
\hline All firms & 333 & 0.151 & 443 & 0.258 & 1363 & 0.149 & 792 & 0.152 & 2931 & 0.167 \\
\hline Small size & 186 & 0.148 & 304 & 0.145 & 737 & 0.110 & 449 & 0.128 & 1676 & 0.126 \\
\hline Large size & 84 & 0.190 & 80 & 0.789 & 404 & 0.206 & 207 & 0.191 & 775 & 0.261 \\
\hline Scale sectors & 98 & 0.140 & 126 & 0.081 & 405 & 0.151 & 201 & 0.210 & 830 & 0.153 \\
\hline Traditional sectors & 160 & 0.129 & 218 & 0.081 & 476 & 0.116 & 300 & 0.104 & 1154 & 0.108 \\
\hline Specialised sectors & 37 & 0.271 & 78 & 0.570 & 418 & 0.164 & 260 & 0.164 & 793 & 0.209 \\
\hline $\begin{array}{l}\mathrm{R} \& \mathrm{D} \text { investing } \\
\text { firms }\end{array}$ & 88 & 0.145 & 172 & 0.550 & 594 & 0.191 & 331 & 0.185 & 1185 & 0.238 \\
\hline
\end{tabular}




\begin{tabular}{|c|c|c|c|c|c|c|c|c|c|c|}
\hline Variable & \multicolumn{2}{|c|}{ South \& isles } & \multicolumn{2}{|c|}{ Centre } & \multicolumn{2}{|c|}{ North-West } & \multicolumn{2}{|c|}{ North-East } & \multicolumn{2}{|c|}{ ITALY } \\
\hline $\begin{array}{l}\text { Hardware } \\
\text { Investment } \\
\text { employee }\end{array}$ & $\begin{array}{l}\text { N. of } \\
\text { obs }\end{array}$ & Mean & $\begin{array}{l}\text { N. of } \\
\text { obs }\end{array}$ & Mean & $\begin{array}{l}\text { N. of } \\
\text { obs }\end{array}$ & Mean & $\begin{array}{l}\text { N. of } \\
\text { obs }\end{array}$ & Mean & $\begin{array}{l}\text { N. of } \\
\text { obs }\end{array}$ & Mean \\
\hline All firms & 333 & 1.718 & 443 & 3.908 & 1363 & 2.811 & 792 & 8.207 & 2931 & 4.311 \\
\hline Small size & 186 & 1.876 & 304 & 2.768 & 737 & 3.777 & 449 & 13.222 & 1676 & 5.914 \\
\hline Large size & 84 & 1.304 & 80 & 9.867 & 404 & 1.675 & 207 & 1.728 & 775 & 2.494 \\
\hline Scale sectors & 98 & 1.276 & 126 & 4.169 & 405 & 5.373 & 201 & 2.074 & 830 & 3.908 \\
\hline Traditional sectors & 160 & 1.614 & 218 & 1.443 & 476 & 1.461 & 300 & 1.399 & 1154 & 1.463 \\
\hline Specialised sectors & 37 & 2.507 & 78 & 4.735 & 418 & 1.858 & 260 & 21.642 & 793 & 8.437 \\
\hline $\begin{array}{l}\mathrm{R} \& \text { \& investing } \\
\text { firms }\end{array}$ & 88 & 2.569 & 172 & 5.823 & 594 & 3.275 & 331 & 17.057 & 1185 & 7.442 \\
\hline Variable & \multicolumn{2}{|c|}{ South \& isles } & \multicolumn{2}{|c|}{ Centre } & \multicolumn{2}{|c|}{ North-West } & \multicolumn{2}{|c|}{ North-East } & \multicolumn{2}{|c|}{ ITALY } \\
\hline $\begin{array}{l}\text { Software Investment } \\
\text { per employee }\end{array}$ & $\begin{array}{l}\begin{array}{l}\text { N. of } \\
\text { obs }\end{array} \\
\end{array}$ & Mean & \begin{tabular}{|l|}
$\begin{array}{l}\text { N. of } \\
\text { obs }\end{array}$ \\
\end{tabular} & Mean & $\begin{array}{l}\text { N. of } \\
\text { obs }\end{array}$ & Mean & $\begin{array}{l}\text { N. of } \\
\text { obs }\end{array}$ & Mean & $\begin{array}{l}\text { N. of } \\
\text { obs }\end{array}$ & Mean \\
\hline All firms & 333 & 1.022 & 443 & 1.982 & 1363 & 2.475 & 792 & 4.356 & 2931 & 2.744 \\
\hline Small size & 196 & 0.997 & 304 & 1.824 & 737 & 3.361 & 449 & 6.513 & 1676 & 3.664 \\
\hline Large size & 84 & 0.959 & 80 & 3.015 & 404 & 1.384 & 207 & 1.546 & 775 & 1.550 \\
\hline Scale sectors & 98 & 0.776 & 126 & 2.273 & 405 & 4.782 & 201 & 1.997 & 830 & 3.253 \\
\hline Traditional sectors & 160 & 0.946 & 218 & 1.310 & 476 & 1.320 & 300 & 1.291 & 1154 & 1.259 \\
\hline Specialised sectors & 37 & 1.495 & 78 & 1.885 & 418 & 1.631 & 260 & 10.114 & 793 & 4.431 \\
\hline $\begin{array}{l}\mathrm{R} \& \quad \mathrm{D} \text { investing } \\
\text { firms }\end{array}$ & 88 & 1.819 & 172 & 2.587 & 594 & 2.537 & 331 & 8.126 & 1185 & 4.052 \\
\hline
\end{tabular}


Tab. 2. ICT investment and productive efficiency: a stochastic frontier estimate (1997 cross-section estimate)

\begin{tabular}{|c|c|c|c|c|c|c|c|c|c|}
\hline \multicolumn{5}{|c|}{ Production Function Variables } & \multicolumn{5}{|c|}{ Technical Efficiency Variables } \\
\hline & Coef. & t-ratio & Coef. & t-ratio & & Coef. & t-ratio & Coef. & t-ratio \\
\hline $\begin{array}{l}\text { Constan } \\
\text { t }\end{array}$ & 3.703 & $\overline{7.326}$ & 3.870 & $\overline{7.591}$ & Constant & -1.371 & -1.810 & 0.118 & 0.164 \\
\hline $\operatorname{Ln}(\mathrm{K})$ & 142 & $\overline{553}$ & .139 & 9.126 & in & -0.763 & -2.385 & -0.558 & -1.827 \\
\hline $\begin{array}{l}\mathrm{Ln}(\mathrm{HSL} \\
\end{array}$ & 800 & 443 & 1.674 & $\overline{226}$ & & 197 & 0.694 & .567 & 03 \\
\hline $\begin{array}{l}\mathrm{Ln}(\mathrm{LSL} \\
)\end{array}$ & 452 & 32 & 383 & $\overline{930}$ & & 85 & 153 & .044 & 0.091 \\
\hline $\operatorname{Ln}(\mathrm{RM})$ & 0.119 & 10.812 & 0.122 & 11.272 & ind4 & -0.658 & -2.303 & -0.612 & -2.319 \\
\hline $\operatorname{Ln}(\mathrm{II})$ & 0.144 & 14.506 & \begin{tabular}{|l|l|}
0.139 \\
\end{tabular} & 13.576 & ind5 & -1.087 & -2.186 & 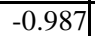 & -2.484 \\
\hline ind1 & 0.345 & 2.919 & 0.317 & 2.158 & ind6 & -0.311 & -0.746 & -0.389 & -1.039 \\
\hline ind2 & 0.067 & 546 & 0.379 & 1.637 & ind7 & -1.349 & -2.401 & -0.845 & -2.07 \\
\hline ind3 & 0.252 & 018 & .236 & $\overline{0.872}$ & ind8 & -1.498 & -1.638 & -1.071 & -1.514 \\
\hline ind4 & -0.186 & -1.686 & -0.258 & -1.855 & inc & -0.157 & -0.440 & -0.126 & -0.342 \\
\hline ind5 & -0.095 & -0.805 & -0.196 & -1.317 & & .076 & 0.147 & 2.586 & 4.285 \\
\hline ind6 & 0.117 & 785 & |0.048 & 280 & ind11 & -0.295 & -1.002 & \begin{tabular}{c|}
-0.293 \\
\end{tabular} & -0.976 \\
\hline ind7 & 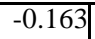 & -1.319 & -0.182 & -1.235 & ind12 & -0.258 & -0.719 & -0.444 & -1.465 \\
\hline ind8 & -0.486 & -2.574 & -0.546 & -2.783 & ind13 & -1.127 & -2.752 & -0.947 & -2.808 \\
\hline ind9 & -0.195 & -1.276 & -0.195 & -0.913 & ind14 & -0.868 & -1.579 & -0.814 & -1.790 \\
\hline ind10 & 0.450 & 2.231 & 2.856 & 4.865 & ind15 & -2.719 & -2.367 & -2.982 & -2.666 \\
\hline ind11 & -0.164 & -1.391 & -0.216 & -1.433 & Ind16 & -2.993 & -2.840 & -3.157 & -3.202 \\
\hline ind12 & $\begin{array}{c}-0.189 \\
\end{array}$ & -1.436 & $\mid-0.279$ & -1.807 & Ind17 & \begin{tabular}{|c|}
-073 \\
\end{tabular} & -2.911 & \begin{tabular}{|c|}
-2.792 \\
\end{tabular} & -3.016 \\
\hline ind 13 & -0.223 & -2.064 & -0.300 & -2.153 & Ind18 & -1.016 & -1.084 & -0.489 & -0.537 \\
\hline ind14 & -0.322 & -2.173 & \begin{tabular}{c|}
-0.400 \\
\end{tabular} & -2.450 & Ind19 & 3.793 & 3.803 & 3.117 & 4.181 \\
\hline ind15 & -0.204 & 313 & \begin{tabular}{|c|c|}
-0.309 \\
\end{tabular} & -1.814 & North- & 0.263 & 1.531 & 0.124 & 1.254 \\
\hline in & -0.544 & .450 & -0.631 & -3.862 & & 0.337 & 1.890 & \begin{tabular}{c|}
0.167 \\
\end{tabular} & 1.571 \\
\hline ind17 & -0.283 & -2.432 & -0.395 & -2.638 & South & 1.087 & 5.177 & |0.623 & 5.281 \\
\hline ind18 & 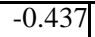 & -1.900 & 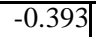 & -1.030 & Young & \begin{tabular}{|l|}
0.144 \\
\end{tabular} & 1.375 & |0.057 & 0.723 \\
\hline $\mathrm{dd} 1$ & 895 & 4.307 & 3.588 & $\overline{5.000}$ & Old & 0.411 & 4.217 & 0.231 & 3.294 \\
\hline
\end{tabular}




\begin{tabular}{|c|c|c|c|c|c|}
\hline \multirow[b]{3}{*}{ Industry Legend } & Group & 0.127 & 1.521 & 0.075 & 1.235 \\
\hline & Csat & -0.060 & -0.669 & -0.023 & -0.356 \\
\hline & Qtnosep & -0.002 & -1.263 & -0.001 & -0.923 \\
\hline \multirow{11}{*}{$\begin{array}{l}\text { Ind1: Food, beverages, tobacco } \\
\text { Ind2: Textile, clothing } \\
\text { Ind3: Leather, shoes } \\
\text { Ind4: Wood and wooden furniture } \\
\text { Ind5: Paper and printing } \\
\text { Ind6: Chemicals } \\
\text { Ind7: Rubber and plastics } \\
\text { Ind8: Glass, ceramics } \\
\text { Ind9: Construction materials } \\
\text { Ind10: Metal extraction } \\
\text { Ind11: Metal products } \\
\text { Ind12: Mechanical materials } \\
\text { Ind13: Mechanical Equipment } \\
\text { Ind14: Electronics } \\
\text { Ind15: Electrical equipment } \\
\text { Ind16: Precision instruments and apparels } \\
\text { Ind17: Vehicles and vehicle components } \\
\text { Ind18: Energy } \\
\text { Ind19: Other manufacturing }\end{array}$} & Family & 0.059 & 0.703 & 0.032 & 0.519 \\
\hline & CSSA & -0.077 & -0.883 & -0.046 & -0.737 \\
\hline & Ration & 0.569 & 2.829 & 0.391 & 2.803 \\
\hline & Rents & 0.019 & 10.607 & 0.016 & 9.085 \\
\hline & Presfi & -0.007 & -0.652 & -0.009 & -1.773 \\
\hline & Innovat & -0.043 & -0.399 & -0.035 & -0.510 \\
\hline & Cap & 0.944 & 1.552 & 0.118 & 0.164 \\
\hline & \begin{tabular}{|l|} 
ICT investment \\
- aggregate
\end{tabular} & -0.005 & -8.261 & & \\
\hline & $\begin{array}{l}\text { Software } \\
\text { investments }\end{array}$ & & & -0.081 & -4.110 \\
\hline & $\begin{array}{l}\text { Hardware } \\
\text { investments }\end{array}$ & & & 0.006 & 1.059 \\
\hline & $\begin{array}{c}\text { Telecommunica } \\
\text { tion investments }\end{array}$ & & & 0.063 & 1.639 \\
\hline & Sigma-squared & 0.468 & 18.123 & 0.366 & 13.391 \\
\hline & Gamma & 0.566 & 12.923 & 0.481 & 8.728 \\
\hline & $\log \mathrm{L}$ & & 1288.48 & & 1265.78 \\
\hline & N. of Obs. & & 1752 & & 1736 \\
\hline
\end{tabular}


Table 3 ICT investment and productive efficiency: synthesis of results from stochastic frontier estimates at industry level

\begin{tabular}{|l|r|r|r|r|r|}
\hline & \multicolumn{1}{|c|}{ Obs. } & Gamma & \multicolumn{1}{c|}{ Sig. } & \multicolumn{1}{c|}{ IT } & \multicolumn{1}{c|}{ Sig } \\
\hline Food, beverages, tobacco & 179 & 0.148 & 2.780 & 0.009 & 0.277 \\
\hline Textile, clothing & $\mathbf{2 4 4}$ & $\mathbf{0 . 8 4 4}$ & $\mathbf{2 . 5 7 2}$ & $\mathbf{- 0 . 0 2 2}$ & $\mathbf{- 2 . 2 6 5}$ \\
\hline Wood and wooden furniture & $\mathbf{1 0 1}$ & $\mathbf{0 . 7 3 5}$ & $\mathbf{7 . 6 4 7}$ & $\mathbf{- 0 . 2 5 3}$ & $\mathbf{- 1 . 7 5 3}$ \\
\hline Paper and printing & $\mathbf{9 7}$ & $\mathbf{0 . 3 6 4}$ & $\mathbf{2 . 5 5 9}$ & $\mathbf{- 0 . 0 1 9}$ & $\mathbf{- 4 . 6 8 1}$ \\
\hline Metal products & 159 & 0.560 & 6.168 & 0.010 & 0.173 \\
\hline Mechanical materials & $\mathbf{7 4}$ & $\mathbf{0 . 4 5 4}$ & $\mathbf{2 . 3 1 2}$ & $\mathbf{- 0 . 0 7 5}$ & $\mathbf{- 3 . 1 5 6}$ \\
\hline Mechanical Equipment & $\mathbf{1 8 1}$ & $\mathbf{0 . 1 3 6}$ & $\mathbf{6 . 1 3 8}$ & $\mathbf{- 0 . 0 2 7}$ & $\mathbf{- 5 . 3 2 4}$ \\
\hline
\end{tabular}

We estimate the model only for those industries for which we have a sufficiently high number of observations $(n>70)$. We use a four factor production function given that low skilled and high skilled labour are highly multicollinear. A few of the other regressors included in the general model presented in tab.2 are singled out on the basis of the VIF factor (VIF>10) which measures multicollinearity with the remaining independent variables. Detailed estimate results are collected in an Appendix available from the authors upon request. 
Aksin, O. Z.; Harker, P. T., 1996, Modeling a Phone Center: Analysis of a Multi-Channel Multi-Resource Processor Shared Loss System, INSEAD Working Papers: 97/57/TM, pp. 38.

Aw, B.Y., A.Hwang, 1995, Productivity and export marker: a firm level analysis, Journal of Development Economics, 47, 209-231.

Baily, Martin Neil and Gordon, R. J. [1988], "The Productivity Slowdown, Measurement Issues and the Explosion of Computer Power", Brookings Papers in Economic Activity, 1988(2): 347-431.

Barua, A., Kriebel, C. and Mukhopadhyay, T. [1991], "Information Technology and Business Value: An Analytic and Empirical Investigation," University of Texas at Austin Working Paper, (May).

Battese, G.E., Coelli, T.J., 1998, prediction of firm-level technical inefficiencies: with a generalised frontier production function and panel data, Journal of Econometrics, 7, 185208.

Becchetti, L., Santoro, M., 2000, The determinants of smallmedium firm internationalisation and its effects on productive efficiency, mimeo

Bender, D. H. [1986], Financial Impact of Information Processing. Vol. 3(2): 22-32.

Berndt, Ernst R. [1991], The Practice of Econometrics: Classic and Contemporary, Addison- Wesley, Reading, MA.

Berndt, Ernst R. and Morrison, Catherine J. [1995], "High-tech Capital Formation and Economic Performance in U.S. Manufacturing Industries: An Exploratory Analysis", Journal of Econometrics 65: 9-43.

Berndt, Ernst R., Morrison, Catherine J. and Rosenblum, Larry S., [1992], "High-tech Capital Formation and Labor Composition in U.S. Manufacturing Industries: an 
Exploratory Analysis," National Bureau of Economic Brooke Research Working Paper No. 4010, (March).

Brynjolfsson. Erik and Hitt, Lorin. [1996], "Paradox Lost? FirmLevel Evidence on the Returns to Information Systems Spending", Management Science, (April)

Brynjolfsson, Erik and Hitt, Lorin. [1995], "Information Technology as a Factor of Production: the Role of Differences among Firms," Economics of Innovation and New Technology, Vol. 3: 183-199.

Chirinko, R.S., 1993, Business Fixed Investment Spending, Journal of Economic Literature 31.

Clausen, C.; Koch, C., 1999, The Role of Spaces and Occasions in the Transformation of Information Technologies-Lessons from the Social Shaping of IT Systems for Manufacturing in a Danish Context, Technology Analysis and Strategic Management, 11(3), September pp. 46382.

Clerides, S.K., Lach, S. and Tybout, 1998, Is learning-byexporting important? Micro-dynamic evidence from Colombia, Mexico and Morocco, Quarterly Journal of Economics, vol CXIII, August, 903-947

Cubbin, J. S. Leech, D., 1983, The Effect of Shareholding Dispersion on the Degree of Control in British Companies: Theory and Measurement, Economic Journal; 93(37), pp. 351-69.

David, Paul A. [1990], "The Dynamo and the Computer and Dynamo: A Historical Perspective on the Modern Productivity Paradox," American Economic Review Papers and Proceedings, Vol. 80(2): 355-361, (May).

Dixit, Pindick , (1994), Investment under uncertainty.

Kiley, M. T., 1999, The Supply of Skilled Labour and SkillBiased Technological Progress, Economic Journal, 109(458), pp. 708-24. 
La Porta, R.; Lopez de Silanes, F.; Shleifer, A., 1999, Corporate Ownership around the World, Journal of Finance; 54(2), 471-517.

Leech, D. and Leahy, J. 1991, Ownership structure, control type classifications and the performance of large British companies, Economic Journal, 101, 1418-1437.

Lehr, B., Lichtenberg, F., 1999, Information Technology and Its Impact on Productivity: Firm-Level Evidence from Government and Private Data Sources, 1977-1993, Canadian Journal of Economics; 32(2), pp. 335-62.

Lichtenberg, Frank R. [1995], "The Output Contributions of Computer Equipment and Personal: A Firm-Level Analysis," Economics of Innovation and New Technology, Vol. 3: 201-217.

Loveman, Gary W. "An Assessment of the Productivity Impact of Information Technologies," MIT Management in the 1990s, Working Paper \# 88 - 05, July 1988.

Loveman, Gary W. [1994], "An Assessment of the Productivity Impact of Information Technologies," in Allen, Thomas J. and Scott Morton, Michael S. (Ed.), Information Technology and the Corporation of the 1990s: Research Studies, Oxford University Press, $\quad$ pp. 84-110.

McConnel, J.J: and Servaes, H., 1990, Additional evidence on equity ownership and corporate value, Journal of Financial Economics, 27, 595-612.

Milgrom P., Roberts R., (1988), The Economics of Modern Manufacturing: Products, Technology and Organization, Stanford Center for Economic Policy Research Discussion Paper 136

Morrison, Catherine J. and Berndt, Ernst. R. [1991], "Assessing the Productivity of Information Technology Equipment in U.S. Manufacturing Industries," National Bureau of Economic Research Working Paper No. 3582, (January). 
Nelson, R. R. [1981], "Research on Productivity Growth and Productivity Differences: Dead Ends and new Departures," Journal of Economic Literature, Vol. 29: 1029-1064.

Nickell, S., 1996, Competition and Corporate Performance, Journal of Political Economy, 104(4), 724-46.

Nickell, S; Nicolitsas, D.; Dryden, N., 1997, What Makes Firms Perform Well?, European Economic Review; 41(35), 783-96.

Oliner, Stephen D. and Sichel, Daniel E. [1994], "Computers and Output Growth Revisited: How Big is the Puzzle?" Brookings Papers on Economic Activity, 1994(2): 273-334.

Roach, Stephen S. [1991], "Services under Siege: the Restructuring Imperative," Harvard Business Review 39(2): 82-92, (September-October).

Roach, Stephen S. [1989b], "America's White-Collar Productivity Dilemma," Manufacturing Engineering , August , pp. 104.

Schwarts, G. and Clements, B., 1999, Government Subsidies, Journal of Economic Surveys, 13, 2, 119-147.

Scott, John T., and Albert N. Link. 1997. "Assessing the Infrastructural Needs of a Technology- Based Service Sector: A New Approach to Technology Policy Planning," Best Practices in Technology and Innovation Policy, Wolfgang Polt (ed.). Organisation for Economic Cooperation and Development, Paris.

Short E, 1994, Ownership, control, financial structure and the performance of firms, Journal of Economic Surveys, 8, 203-249.

Sichel, Andrew. 1997. The Computer Revolution: An Economic Perspective. Brookings Institution Press, Washington, DC.

Stiroh, K.J., 1998, Computers productivity and input substitution, Economic Inquiry, 36,2, April, 175-91. 
Strassmann, P. A. [1990], The Business Value of Computers: An Executive's Guide. New Canaan, CT, Information Economics Press.

Vickers J., 1995, Concepts of Competition, Oxford Economic Papers; 47(1), January, pp. 1-23.

Wright, D. T.; Burns, N. D., 1997, Cellular Green-Teams in Global Network Organisations

International Journal of Production Economics; 52(3), October, pp. 291-303. 
To consider the impact of ICT investment on different dependent variables we formulate a comprehensive model with six types of general controls plus specific controls which may be relevant for the selected dependent variable.

The specification adopted is:

$$
\begin{aligned}
& I O=\alpha_{\theta}+\sum_{i=1}^{m-1} \alpha_{l} I n d_{l}+\sum_{j=1}^{p-1} \delta_{j} \text { Pavitf }+\sum_{k=1}^{n-1} \gamma_{k} \text { Macroaręt } \sum_{l=1}^{d-1} \alpha_{l} I d e n t i t y+\sum_{f=1}^{g-1} \delta_{f} \text { Ownershipp } \\
& +\sum_{s=1}^{w-1} \gamma_{s} \text { Finançe+ } \sum_{r=1}^{z-1} \gamma_{r} I P H C_{r}+\sum_{q=1}^{y-1} \gamma_{q} I T V_{q}+\varepsilon
\end{aligned}
$$

where $I O$ is the selected intermediate variable (utilisation capacity, hiring rate of skilled workers, introduction of new products or processes, net sales per employee) measured in 1997. Given the distributions of these dependent variables (see tab. A.1.1) we adopt a right censored Tobit model for utilisation capacity, a left censored Tobit model for the hiring rate of skilled workers, a Logit model for the introduction of new products or processes and least squares for net sales per employee. Since dependent variables are not normally distributed (see tab. A 1.1) we estimate confidence intervals for regressors coefficients with bootsrapping techniques (we adopt the percentile method with 1000 replications). In the case of the net sales per employee estimate we check whether the impact of regressors are significant not only on conditional mean but also on conditional median.

Our groups of general controls are:

i)IND are $m-1$ industry dummies based on a three-digit ATECO classification $(m=1, . ., 20)$, 
ii)PAVITT are $p$ - 1 macrosector dummies $(p=1, . ., 4),{ }^{14}$

iii) MACROAREA are $n-1$ macroarea dummies $(n=1, \ldots, 4)$,

iv) IDENTITY (three variables): SIZE are firm's employees in 1995, BIRTH is the firm's year of establishment, EXPORT is a dummy for exporting firms.

v) OWNERSHIP (six variables): GROUP is a dummy which takes value of one for firms affiliated to groups (subsidiaries or parent companies) and zero otherwise; FAMILY is a dummy which takes value of one if the firm is "family controlled" (all controllers are linked by kinship) ${ }^{15}$, SOCBANK is a dummy for firms having financial intermediaries among controlling shareholders. ${ }^{16}$ CONPUB is a dummy for firms in which the government is a controlling shareholder, $C M S$ is a dummy for firms with controlling minority shareholders (the control group owns less than 40 percent of firm capital), CNTRNM is the number of controlling shareholders and is introduced as a proxy for coordination costs.

vi) FINANCE (five regressors on the availability and costs of external and internal finance): SUBSIDY is a dummy indicating if

\footnotetext{
${ }^{14}$ These are three of the four Pavitt dummies (Scale, Specialised, High-Tech and Traditional sectors). We adopt both the Pavitt and the 21-sector extended classification since firms within the same sector often belong to different Pavitt macrosectors. The inspection of the correlation matrix shows that this choice does not create severe multicollinearity problems in the estimate. The correlation matrix is available from the authors upon request.

${ }^{15}$ La Porta et al. (1999) have recently emphasized the importance of family ownership on corporate structure in the world. They find that family owned firms represented from 60 to 80 percent of firms with a market capitalisation of at least 500 million dollars in Italy, up to 40 percent in the UK and 20 percent in the US in 1995. Countries like Israel, Honk Kong, Mexico, Argentina and Sweden all had a share of family owned firms higher than 50 percent in the same year.

${ }^{16}$ When financial intermediaries are also controlling shareholders the traditional divergence of incentives existing between (lenders) financiers and entrepreneurs is eliminated. Therefore it should be easier for firms to finance investment in risky activities.
} 
the firm received soft loans, $A G E V O L$ is a dummy for firms which received tax allowances in the 1995-97 period, RATION is a dummy indicating type I or type II credit rationing (the firm declares she asked and did not received credit (additional credit) at the prevailing rate in the considered period), $L E V$ is the 1995 ratio of debt versus banks to total assets, ${ }^{17}$ CONFIDI is a dummy for firms affiliated to credit consortia, PRESFI measures firm financial pressure and is calculated as interest expenditures /(gross profits + depreciation + interest expenditures), NBANC is a proxy for multiple borrowing and is the number of banks with whom the firm has relationship, $Q P B A N C$ is the share of the first lender on firm bank debt

vii) INNOVATION, HUMAN AND PHYSICAL CAPITAL (four controls for technological innovation): INNOVAT is a dummy taking value of one if the observed firm declares to have successfully innovated their products or processes, $R \& D I N V$ is a dummy for firms with nonzero $R \& D$ investment in 1995 , QLWSK is the 1995 share of low skilled workers on total employees, CAPAD is capital intensity or the stock of physical capital per employee.

viii) ITV (vector of information technology variables): ITXASOF, ITXAHAR, ITXATEL and ITXTELG are respectively the 19951997 investment in software, hardware, telecommunications and telecommunications for firms participating to groups only. All these variables are scaled for the total number of firm employees.

\footnotetext{
${ }^{17}$ In balance sheet data the following debt items are registered: i) debt versus banks; ii) debt versus partners; iii) debt versus group; iv) debt versus suppliers customers anticipated payments; v) bonds. Items ii) and iii) should be considered as equity more than debt, because non individual firms are often participated with a share higher than $50 \%$. Item iv) is commercial debt more linked to operating expenses than to investment financing. We use total assets and not equity capital as a scale variable because all firms are small and medium sized, not listed in the stock exchange and most of them family owned. As a consequence, equity capital is often a symbolic balance sheet item, extremely volatile and not representative of firm's stock of total assets.
} 
We decide to use so many controls in order to reduce the possibility of omitted variable bias. In our case we want to avoid that the significance of ICT variables be explained by correlations with omitted regressors and that the former are in reality significant because they proxy for other hidden factors which are the true determinants of our observed dependent variables. On the other hand, though, we are aware that overparametrisation leads to reduced efficiency (too high standard error) and potential multicollinearity among ICT regressors. In that case insignificant controls may ultimately reduce the effective impact of ICT on the dependent variable. It is well known that a comparison in terms of mean squared errors shows then that it is better to omit the variable if the coefficient of the omitted variable is small and insignificant and if there is small correlation between excluded and included. For this reason after using the overparametrised specification we adopt a stepwise backward approach to reduce the number of regressors. The test for omission of redundant variable is performed at constant number of observations and the order of deletion follows that of the coefficient lowest significance. Results of estimates including all controls are shown in tab A1.2 while final results from the stepwise backward approach are presented in tab. A1.3. 
Tab A.1.1 Percentile distribution and normality tests for dependent variables of econometric estimates in Tab. A1.2

\begin{tabular}{|c|r|r|r|}
\hline \multicolumn{1}{|c|}{ Percentile } & Fatad97 & Dhsk & \multicolumn{1}{c|}{ Cap97 } \\
\hline 10 & 133.572 & 0.000 & 0.70 \\
20 & 169.263 & 0.000 & 0.70 \\
30 & 200.000 & 0.000 & 0.80 \\
50 & 231.250 & 0.000 & 0.80 \\
60 & 267.653 & 0.000 & 0.85 \\
70 & 309.989 & 0.000 & 0.90 \\
80 & 369.003 & 0.000 & 0.90 \\
90 & 468.196 & 0.000 & 0.95 \\
100 & 637.343 & 0.011 & 1.00 \\
Mean & 19417.850 & 0.654 & 1.00 \\
Obs & 368.634 & 0.004 & 0.831 \\
& 4445 & 3317 & 4309 \\
\hline \multicolumn{3}{|c|}{ Normality tests } \\
\hline Shapiro Wilk Z & 19.472 & 18.109 & 12.020 \\
P-value (reject the & 0.9999 & 0.9999 & 0.9999 \\
null) & 4.966 & 6.565 & 4.385 \\
Shapiro Francia Z & 0.9999 & 0.9999 & 0.9999 \\
P-value(reject the & & \\
null) & & \\
\hline
\end{tabular}

Fatad97: Net sales per employee in 1997; Dhsk: Demand for high skilled workers in 1997; Cap: capacity utilisation in 1997 
Tab A1.2 The effect of ICT investment on intermediate and productivity variables

\begin{tabular}{|c|c|c|c|c|c|c|c|c|c|c|c|c|}
\hline & \multicolumn{2}{|c|}{$\begin{array}{c}\text { Demand for high } \\
\text { skilled workers } \\
\text { (l.c. Tobit) }\end{array}$} & \multicolumn{2}{|c|}{$\begin{array}{c}\text { Introduction of } \\
\text { new products }\end{array}$} & \multicolumn{2}{|c|}{$\begin{array}{c}\text { Introduction of } \\
\text { new products and } \\
\text { processes }\end{array}$} & \multicolumn{2}{|c|}{$\begin{array}{l}\text { Capacity } \\
\text { utilisation } \\
\text { (r.c.Tobit) }\end{array}$} & \multicolumn{2}{|c|}{$\begin{array}{l}\text { Net sales per } \\
\text { employee } \\
\text { (conditional } \\
\text { mean) } \\
\end{array}$} & \multicolumn{2}{|c|}{$\begin{array}{l}\text { Net sales per } \\
\text { employee } \\
\text { (conditional } \\
\text { median) } \\
\end{array}$} \\
\hline & Coef. & b.s.e. & Coef. & $\mathrm{Z}$ & Coef. & $\mathrm{Z}$ & Coef. & b.s.e. & Coef. & b.s.e & Coef. & b.s.e \\
\hline Ind-01 & 0.036 & $0.015^{* *}$ & 0.938 & 1.240 & 0.664 & 0.896 & -10.410 & $4.093 * *$ & & 187.049 & 209.526 & $62.461 *$ \\
\hline Ind-02 & 0.015 & 0.011 & 1.770 & 2.506 & 1.101 & 1.607 & -6.505 & 3.784 & & 114.121 & & 43.327 \\
\hline \begin{tabular}{|l|} 
Ind-03 \\
\end{tabular} & -0.030 & 0.179 & 1.010 & 1.152 & 0.059 & 0.062 & -1.682 & 4.659 & -58.227 & 139.481 & 63.638 & 72.699 \\
\hline Ind-04 & 0.024 & $0.014 * *$ & 1.998 & 2.618 & 1.700 & 2.274 & -8.509 & $4.327 * *$ & & 135.866 & & 47.531 \\
\hline Ind-05 & 0.005 & 0.007 & 0.400 & 0.766 & 0.396 & 0.720 & -3.001 & 3.292 & & 178.428 & & 39.178 \\
\hline Ind-06 & 0.006 & 0.007 & 0.841 & 1.748 & 0.814 & 1.673 & 0.005 & 3.292 & -9.306 & 115.027 & 97.466 & $45.626^{*}$ \\
\hline Ind-07 & -0.003 & 0.008 & 0.998 & 2.305 & 0.726 & 1.557 & -2.886 & 2.584 & -94.737 & 99.839 & & 28.550 \\
\hline Ind-08 & -0.002 & 0.008 & 0.417 & 0.720 & 0.123 & 0.200 & -2.104 & 3.055 & & 124.696 & & 49.372 \\
\hline \begin{tabular}{|l|} 
Ind-09 \\
\end{tabular} & 0.007 & 0.022 & 0.375 & 0.478 & 0.584 & 0.767 & -4.762 & 3.841 & & 203.090 & & 54.969 \\
\hline Ind-10 & 0.008 & 0.008 & 0.713 & 1.379 & 0.886 & 1.676 & -4.472 & 3.332 & & 190.569 & 10 & $58.787 *$ \\
\hline Ind-11 & 0.017 & $0.010 * *$ & 1.660 & 2.635 & 1.521 & 2.503 & -6.926 & $3.262 * *$ & & 100.903 & & 34.950 \\
\hline \begin{tabular}{|l|} 
Ind-12 \\
\end{tabular} & 0.004 & 0.008 & 1.425 & 2.792 & 0.736 & 1.420 & 0.610 & 3.197 & -4.201 & 67.167 & 40.408 & 37.749 \\
\hline Ind-13 & .004 & 0.006 & 0.755 & 1.844 & 0.438 & 1.004 & 0.838 & 2.562 & -22.490 & 52.180 & 8.283 & 24.855 \\
\hline Ind-14 & 0.014 & 0.010 & 0.559 & 0.867 & 0.211 & 0.324 & 2.988 & 3.926 & -1.216 & 110.228 & & 53.772 \\
\hline Ind-15 & 0.016 & $0.008 * *$ & 216 & 0.264 & .009 & 0.010 & -6.115 & 3.194 & & 77.565 & & 38.796 \\
\hline Ind-16 & & & 167 & 1.130 & 1.398 & 1.336 & 1 & & -35.736 & 127.367 & & 46.651 \\
\hline Ind-17 & 0.010 & 0.007 & 0.683 & 1.419 & 0.461 & 0.919 & -2.416 & 3.049 & -75.139 & 67.320 & & 26.148 \\
\hline \begin{tabular}{|l|} 
Ind-18 \\
\end{tabular} & & & 0.575 & 0.571 & 0.612 & 0.630 & 3.515 & 5.228 & -88.597 & 136.015 & & 106.003 \\
\hline Ind-19 & - & - & 1.704 & 1.779 & 1.729 & 1.579 & -1 & & & 1470.97 & 34 & 1919.84 \\
\hline Scala & -0.002 & 0.007 & -0.047 & -0.094 & -0.129 & -0.272 & 2.619 & 2.932 & & 83.799 & & 38.930 \\
\hline Sp & .001 & 0.008 & 0.024 & 0.048 & -0.081 & -0.169 & 2.296 & 3.123 & -3.492 & 83.643 & & 41.074 \\
\hline Tradiz & -0.002 & $0.012 *$ & -1.079 & -1.462 & -0.775 & -1.111 & 5.715 & 3.658 & & 112.071 & & 46.404 \\
\hline Novest & 0.0008 & 0.004 & -0.333 & -1.294 & -0.421 & -1.624 & -0.527 & 1.491 & & 60.479 & 4.552 & 21.785 \\
\hline Nest & .003 & 0.005 & -0.524 & -1.863 & -0.751 & -2.579 & -0.652 & 1.651 & & 83.776 & 8.718 & 25.804 \\
\hline Sud & 0.009 & 0.009 & -0.311 & -0.777 & -0.195 & -0.502 & -2.272 & 1.998 & -80.467 & 83.497 & & 34.163 \\
\hline Size & & 0.00000 & 0.0001 & 0.574 & 0.0001 & 0.722 & 0.001 & 0.001 & -0.043 & 0.079 & 0.010 & 0.021 \\
\hline Birth & & 0.00007 & 0.006 & 1.214 & 0.006 & 1.462 & -0.060 & $0.025^{* *}$ & -1.007 & 0.804 & & 0.328 \\
\hline Export & 0.012 & $0.005 * *$ & 0.287 & 1.164 & 0.144 & 0.583 & -1.091 & 1.284 & & 132.642 & 20.511 & 19.517 \\
\hline Group & 0.019 & $0.004 * *$ & -0.124 & -0.608 & 0.177 & 0.925 & -0.632 & 1.057 & & 34.283 & 21.470 & 15.499 \\
\hline Family & -0.004 & 0.003 & -0.373 & -1.937 & -0.424 & -2.134 & 0.359 & 1.098 & -22.972 & 66.510 & 5.984 & 14.462 \\
\hline Socbank & 0.006 & $0.004 *$ & 0.074 & 0.251 & 0.169 & 0.615 & -0.380 & 1.553 & & 157.923 & & 27.136 \\
\hline Contpub & -0.034 & $0.065^{* *}$ & 0.818 & 1.099 & 1.133 & 1.508 & -3.510 & 3.557 & -2.242 & 146.341 & & 50.573 \\
\hline $\mathrm{Cms}$ & & & -1.819 & -1.795 & -1.386 & -1.344 & - & & 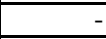 & 170.874 & 16.615 & 85.661 \\
\hline Cntrnm & 0.001 & 0.001 & -0.017 & -0.160 & -0.056 & -0.513 & 0.191 & 0.568 & & 27.159 & & 7.253 \\
\hline \begin{tabular}{|l|} 
Subsidy \\
\end{tabular} & -0.002 & 0.005 & -0.560 & -1.354 & -0.574 & -1.554 & 1.211 & 2.383 & & 57.907 & 23.045 & 23.396 \\
\hline \begin{tabular}{|l|} 
Agevol \\
\end{tabular} & 0.013 & $0.006^{* *}$ & 0.844 & 2.021 & 0.926 & 2.452 & -1.928 & 2.381 & -1 & 83.631 & & 23.346 \\
\hline Ration & 0.014 & $0.006 * *$ & 1.611 & 3.060 & 1.502 & 3.198 & -3.396 & 2.912 & & 91.874* & & $29.869 *$ \\
\hline Lev & -0.004 & 0.008 & -0.307 & -0.596 & -0.150 & -0.287 & 4.856 & 2.912 & & 122.973 & 50 & $3.559 *$ \\
\hline
\end{tabular}




\begin{tabular}{|c|c|c|c|c|c|c|c|c|c|c|c|c|}
\hline Confidi & 0.015 & 0.008 ** & 0.784 & 2.123 & 0.704 & 2.145 & -0.640 & 1.483 & -15.364 & 51.949| & & 24.330 \\
\hline Prefi & -0.0001 & $\begin{array}{l}0.0009 \\
\end{array}$ & -0.089 & -1.451 & -0.063 & \begin{tabular}{|l|l|}
-1.193 \\
\end{tabular} & 0.068 & 0.418 & -0.289 & 14.116 & & 5.645 \\
\hline Nbanc & 0.0001 & (0.0002 & 0.023 & 1.338 & 0.024 & 1.446 & 0.049 & 0.084 & & 12.125 & 0.769 & 1.461 \\
\hline Qpbanc & & 0.00005 & 0.002 & 0.838 & 0.003 & 0.980 & -0.064 & $0.017 * *$ & & $0.977 *$ & 0.003 & 0.252 \\
\hline Innovat & -0.001 & 0.004 & & & & & -0.866 & 1.260 & & 47.165 & 25.230 & 17.414 \\
\hline Rdinv & 0.001 & 0.003 & 0.569 & 3.264 & 0.575 & 3.207 & -1.999 & $1.014 * *$ & & 53.129 & & 13.633 \\
\hline Qlwsk & 0.365 & $0.267 * *$ & 0.495 & 0.132 & 0.688 & 0.210 & -13.078 & 27.843 & -96.530 & 1142.75 & 925.243 & 921.320 \\
\hline Capad & & 0.00002 & $\begin{array}{l}-0.002 \\
\end{array}$ & -2.078 & $\mid-0.002$ & \begin{tabular}{|c|}
-1.625 \\
\end{tabular} & 0.008 & 0.010 & & $1.560 * *$ & 1.030 & $0.203 * *$ \\
\hline Amm & 0.005 & 0.010 & & & & & 1.530 & 4.605 & & & & \\
\hline Itxasof & 0.001 & $0.0008^{*}$ & -0.006 & -0.142 & -0.005 & -0.108 & 0.054 & 0.258 & & $35.293 *$ & 15.442 & 6.867**| \\
\hline Itxahar & -0.0003 & 0.0005 & -0.076 & -2.513 & -0.031 & -0.946 & -0.041 & 0.197 & -2.679 & 17.210 & & 7.010 \\
\hline itxatel & 0.002 & 0.002 & 0.315 & 0.881 & 0.938 & 2.762 & -3.641 & 1.891 & & $81.866^{*}$ & & 18.215 \\
\hline Itxtelg & & & 1.073 & 2.105 & & & 4.583 & $2.274 * *$ & & & & \\
\hline Cons & & & -0.823 & -1.084 & \begin{tabular}{|c|}
-1.152 \\
\end{tabular} & -1.505 & & & 3.316 & $1.560^{* * *}$ & 135.433 & \begin{tabular}{|l|l|}
$60.486^{*}$ \\
\end{tabular} \\
\hline $\mathrm{F}$ & & 69.56 & & Wald & & Wald & & 3.79 & & 2.23 & & \\
\hline R sq. & & 0.18 & & 0.12 & & 0.12 & & 0.09 & & 0.29 & & \\
\hline N. of & & 866 & & 761 & & 761 & & 883 & & 905 & & \\
\hline
\end{tabular}


Tab A1.3 The effect of ICT investment on intermediate and productivity variables (bootstrap stepwise regression estimates)

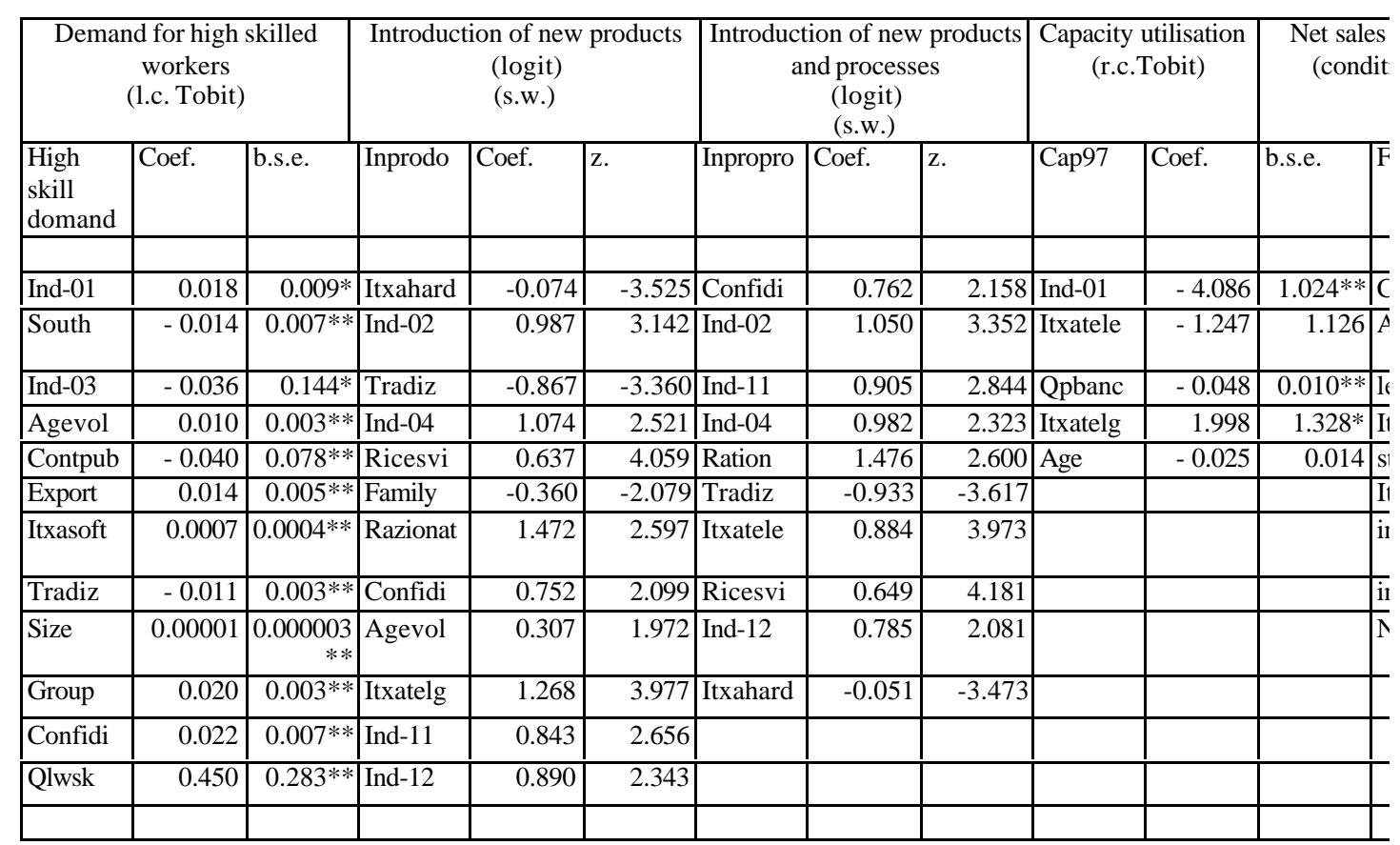

** significant at $95 \%$ with two methods to compute confidence intervals: bias-corrected and percentile.

* $\quad$ significant at $95 \%$ with one method to compute confidence 
Appendix 2

Hypothesis 3: investment in Information Technology increases the value of the firm by adding a flexibility option whose effects is that of increasing on average capacity utilisation

Consider the case of an entrepreneur which must invest in additional capacity and has not invested in ICT. The entrepreneur knows that in $t_{1}$ there will be a taste shock which will affect the demand of the product generated with additional capacity. The model is in two periods.

Additional capacity will therefore yield to him extra revenues generated by the following process: $\mathrm{X}$ in $t_{0}$ and $X(1+g)$ in $t_{1}$ if the shock increases the demand for the product (with prob $p$ ) and $X(1-d)$ if the shock reduces the demand for the product (with prob $1-p)$. The non ICT entrepreneur must decide now because: i) either he has not the technology to know in real time consumer tastes (know in $t_{l}$ the realisation of the shock in $t_{l}$ ) or ii) because its productive process cannot be adapted in $t_{1}$ (extra additional capacity cannot be added) to produce in $t_{1}$. In other terms we postulate that an investment in telecommunications has a B2C (business to consumer) and a B2B (business to business) effect. The first allows, through internet communication, to know in real time consumer tastes and the demand for differentiated products of the firms. The second allows, through internet and intranet communication, the reduction of production lags and informational asymmetries among subcontractors and component producers at different levels of the chain value (i.e. internet auctions among subcontractors in "digital markets" increase the number of participants, reduce transaction costs and reduce lags between the definition of product characteristics and its availability to final consumers). In our model this creates for the ICT investing firm the possibility to invest and adapt production in $t_{1}$ after knowing consumer tastes in the same period. 
The value of its investment in extra capacity will be: $\Omega_{N I T}=\max \left\{V_{0}-I, 0\right\}$ where $V_{0}=X+[X(1+g) p+X(1-d)(1-p)](1 /(1+r))$ or $V_{0}=X+[X(1+p(g+d)-d)](1 /(1+r))$. The entrepreneur which has invested in information technology (and in telecommunications technology) may know in real time consumer tastes on its web site and has eliminated lags between changes in productive capacity and final production. Therefore the value of its investment changes into: $\Omega_{I T}=\max \left\{V_{0}-I, \frac{E_{0}\left[F_{1}\right]}{1+r}\right\} \quad$ where $E_{0}\left[F_{1}\right]=p * \max [X(1+g)-I, 0]+(1-p) * \max [X(1-d) \quad-I, 0] .^{18}$ is the expected value today of the continuation value. The investment in ICT will therefore increase the value of the ICT investing firm by the flexibility option which is equal to $\Omega_{I T}-\Omega_{N I T}$. It is obvious then that there will be values of $g, d, p$ such that: $0<V_{0}-I<\frac{E_{0}\left[F_{1}\right]}{1+r}$. If this condition holds the ICT entrepreneur will find it optimal to wait in $t_{0}$ and the non ICT entrepreneur will find it optimal to invest in additional capacity. As a result, capacity utilisation will be higher for the ICT entrepreneur in $\mathrm{t}$ if the negative shock is realised (with probability $(1-p)$ ) as, with the negative shock, the additional capacity $\mathrm{I}$ is too much to produce just $X(1-d)$. The inequality holds when $V_{0}-I>0\left(N C_{l}\right)$ if

$X+[X(1+p(g+d)-d)](1 /(1+r))-\mathrm{I}<[p * \max [X(1+g)-I, 0]+$ $+(1-p) * \max [X(1-d)-I, 0]](1 /(1+r))$

In choosing whether to postpone the investment the ICT entrepreneur therefore trades off the advantage from investing soon (the present cash flow from the investment in $t(\mathrm{X})$ ) with the advantage from waiting and avoiding to invest under the bad state of nature in $t_{1}$ and from reducing the expected cost of the

${ }^{18}$ Note that, from a mathematical point of view the flexibility option shifts the probability of the realisation of the state of nature before the max operator. In other terms, the advantage of postponing the investment decision is that the decision can be taken after the state of nature in $t_{1}$ has been observed. 
investment. Therefore if $X>\operatorname{Ir} /(1+r)$, it is convenient to wait only if the investment would give nonpositive returns in case the bad state of nature is realised. It is therefore clear that the value of the option to wait is increasing in the discount rate and - if the value of the project is non positive under the negative shock - in the size of the negative shock, while it is decreasing in the project value.

To check whether the same arguments hold in continuous time and with a slightly more complicated stochastic process for returns from the project of investing in additional capacity, consider the following argument developed by following the standard Dixit-Pindick (1994) approach .

Let the return from investing in additional capacity follow the geometric Brownian motion: $d Y=\alpha Y d t+\sigma Y d z$ where $d z$ is the increment of a Wiener process so that $E[d z]=0$ and $\operatorname{Var}[d z]=d t$. Remember that $Y$ represents the present value of the investment in additional capacity and therefore the discounted sum of cash flow from the investment at the time the investment itself is taken. Consider the payoff from investing now: $\Omega_{Y o}=\max \left\{Y_{0}-I, 0\right\}$ and the payoff from holding the option to invest in the future $\Omega_{Y}=F(Y)=\max E\left\{\left(Y_{T}-I\right) e^{-\mathrm{p} T}\right\}$ where $\mathrm{T}$ is the period in which the firm finally decides to expand its capacity. We are in the continuation region if $\Omega_{Y}>\Omega_{Y o}$. In this region the following no arbitrage condition holds: $\rho F(Y) d t=E[d F(Y)]$ where we have the appreciation at the normal market return of a sum corresponding to the value of the option on the left hand side and the change in value of the option to wait in the same interval on the right hand side. By applying Ito's lemma, taking expectation and simplifying we get the following second order (homogenous-constant coefficient) differential equation: $F_{t}+\alpha Y F_{Y}+\frac{1}{2} \sigma^{2} Y^{2} F_{Y Y}-\rho F=0$.

The differential equation has the usual three boundary conditions: $F(0)=0(\mathrm{~A} 2.1), F\left(Y^{*}\right)=Y^{*}-I \quad(A 2.2), F^{\prime}\left(Y^{*}\right)=1 \quad(A 3.3)$

The first is the obvious consequence of what happens to a geometric Brownian motion when $Y=0$. The second is the value 
matching condition, which implies that the gain from investing net of the opportunity cost is equal to the cost of investing. Finally (A2.3) is the smooth pasting condition requiring that not only levels but also first derivatives of the holding option and the termination payoff match at the optimum.

The trial solution which satisfies (A2.1) is $F(Y)=A V^{\beta 1}$. By replacing this solution in (A2.2) and (A2.3) we find the usual values for $A$ and $Y^{*}$ with $Y^{*}=\frac{\beta_{1}}{\beta_{1}-1} I$. To solve for the value of $\beta_{I}$ we replace the trial solution in the second order differential equation and simplify to obtain: $F_{t}+\alpha Y F_{Y}+\frac{1}{2} \sigma^{2} \beta(\beta-1)+(\rho-\delta)-\rho=0$. This second order equation gives two roots: $\beta_{1}>1$ and $\beta_{2}<0$. Given the range of values that $\beta_{I}$ can take the following inequality may hold: $Y^{*}<Y<I$. When Y takes values which respect this inequality the non ICT firm will invest in additional capacity but the ICT firm will find it optimal to wait. A subsequent fall in the value of the returns from the project will therefore generate the result of a lower capacity utilisation for the ICT firm.

$Y^{*}<Y<I$ may occur even in the case of a deterministic process similar to the previous one except for $\sigma=0$. In this case in fact it is possible to find the time at which the option to increase productive capacity is exercised. We have in fact $\Omega_{Y}=\left\{\left(Y e^{-\alpha T}-I\right) e^{-\rho T}\right\}$. After rearranging first order condition we get: $T^{*}=\max E\left\{\frac{1}{\alpha} \log \left[\frac{\rho I}{(\rho-\alpha) Y}\right], 0\right\}$. It is clear than that if $\mathrm{Y}$ is not too higher than I it is better to wait for the ICT firm while it is impossible to do it for the non ICT firm.

Hypothesis 4: investment in telecommunications reduces average productivity of labour 
Consider the same model presented in the previous section with the only difference that now the ICT firm not only has the advantage of more productive flexibility, but also that to adapt its product or process to new consumer tastes. For the ICT firm now the return from the project assumes the form of $d Y^{N}=\alpha_{1} Y^{N} d t+\sigma Y^{N} d z$ with $Y^{N}$ being the return from the new product, $\alpha_{1}>\alpha$ and $I_{1}>I$. The difference in investment costs is given by the reduction of sales per employee at the moment the new product or process is developed due to training costs of the existing personnel.

Consider the payoff from investing now: $\Omega_{Y o}=\max \left\{Y_{0}-I, 0\right\}$ and the payoff from holding the option to invest in the future $\Omega_{Y}=F\left(Y, Y^{N}\right)=\max E\left\{\left(Y^{N}{ }_{T}-I_{N}\right) e^{-\rho T}\right\}$. The same analysis of proposition 3 may be developed with the difference that, whenever the ICT firm invests, it incurs in higher sunk costs than in the previous case as sunk costs include the costs of retraining personnel. Therefore, given that in any instant of time there will be a positive probability that an ICT firm invests and incurs in labour retraining costs, its average productivity of labour will be lower. 